\title{
A REviEw of RoBIN Hood ScHOLARSHIP PUBLISHEd IN 2016
}

\author{
Gayle Fallon \\ Louisiana State University
}

Several developing trends are apparent in the peer-reviewed Robin Hood scholarship of 2016, such as an increase in applications of spatial theory and eco-criticism. ${ }^{1}$ Prevalent themes in the works reviewed below include the polysemy of Robin Hood's character, the embodiment of outlaw tales through play/games and drama, the remarkably complex significance of outlaw feasts, and popular anxieties related not only to the legal and ecclesiastical powers challenged in outlaw narratives, but also to the outlaws who challenge them.

Despite many shared themes in the year's Robin Hood scholarship, it is difficult to sort these works into like categories, as several authors examine disparate texts from the Robin Hood tradition, and even more incorporate multiple theoretical methods in their analyses. Thus, I have followed the example set by Mikee Delony in her excellent review of the previous year's scholarship: works are separated into broad genres and chronological groupings. ${ }^{2}$

\section{General STUdies}

Telling Tales and Crafting Books: Essays in Honor of Thomas H. Ohlgren, ${ }^{3}$ edited by Alexander L. Kaufman, Shaun F. D. Hughes, and Dorsey Armstrong, contains a collection of essays that harmonizes with the research and pedagogical pursuits of scholar Thomas H. Ohlgren. An obvious and abiding love for the well-told tale threads through the volume, reminding readers that they should revel in the story, in "its ability to entertain, instruct, console, and inspire" (1). Ohlgren's work and teaching have encouraged scholars to expect pleasure when approaching a medieval text; likewise, this collection encourages readers to embrace the myrth created by the study of medieval works (2).

The volume is divided into three sections that reflect the wide scope of Ohlgren's own specializations: "Old English and the North," "The Robin Hood Tradition," and "Manuscripts, Books, and Medieval Literature." The second section, which contains five essays related to Robin Hood studies, may be of the most interest to those reading this review. Stephen Knight's chapter "Feasts in the Forest" surveys a wide variety of outlaw-hosted meals in different media, from feasts

\footnotetext{
${ }^{1}$ An impressive amount of work related to Robin Hood studies was published in 2016. This review covers one book, thirteen book chapters, and ten articles. Though not reviewed in this essay, one 2016 encyclopedia entry may also be useful to those who would like a brief introduction to the history of the Robin Hood legend-see Folk Heroes and Heroines around the World, 2nd ed., s.v. "Hood, Robin (England)."

${ }^{2}$ Mikee Delony, "A Review of the Year's Publications in Robin Hood Scholarship," The Bulletin of the International Association for Robin Hood Studies 1 (2017): 32-43.

${ }^{3}$ Alexander L. Kaufman, Shaun F. D. Hughes, and Dorsey Armstrong, eds. Telling Tales and Crafting Books: Essays in Honor of Thomas H. Ohlgren, Festschriften, Occasional Papers, and Lectures XXIV (Kalamazoo: Medieval Institute Publications, 2016). For a more thorough overview of this work, see Valerie B. Johnson's review in Arthuriana 27, no. 1 (2017): 139-42.
} 
in medieval ballads to celebratory scenes in modern films. Knight reveals how the outlaw festal tradition consistently signals both self-sufficiency and a willingness to challenge society. Unpretentious meals of venison and ale, for example, generate a spirit of satisfaction, bonhomie, and reconciliation. However, when an unwilling guest is present or when an outlaw arrives at a feast in disguise, the meal can "act in ironic mode" to discover how Robin Hood's trickster aspects "[enable] him to triumph and celebrate at the same time" (170). An insufficient feast-such as those featured in Munday's The Downfall of Robert, Earle of Huntingdon and The Death of Robert, Earle of Huntingdon - can indicate overwhelming loss, an evacuation of the agency and influence connoted by yeoman feasts. This chapter chimes well with Melissa Ridley Elmes's article ${ }^{4}$ concerning outlaw feasting and its relationship to the characterization of Robin Hood. Just as Elmes addresses the polysemous nature of Robin Hood, so Knight addresses the polysemous nature of Robin's feasts.

John Marshall's "Show or Tell? Priority and Interplay in the Early Robin Hood Play/Games and Poems" explores the relationship between the early Robin Hood ballads and medieval play/games, complicating arguments that have favored either the ballads or the play/games as the origin of the other. Marshall bases his work on the many historical documents that mention Robin Hood performances, also noting that many more Robin Hood performance events are likely hidden in medieval accounting books that contain records of household expenditures but lack detailed line itemization. He takes special care to reveal motifs in Robin Hood ballads and play/games that appear in local celebrations during Whitsuntide and Rogationtide. The focus on the latter is especially important, since Rogationtide is largely ignored as a subject in Robin Hood scholarship. Ultimately, Marshall proposes that, at the least, the play/games competitions inspired the humorous "meets his match" episodes of the Robin Hood tradition, though the play/games could have plausibly contributed to the formation of much more in Robin Hood literature.

In “"... something of the air of a celebration': Scott, Peacock, and Maid Marian," Alan T. Gaylord suggests that Thomas Love Peacock's Maid Marian is filled with echoes of Sir Walter Scott's Ivanhoe, but these echoes, Gaylord says, are oblique - they resonate with twisted and inverted tropes from Scott's novel. Peacock therefore effectively satirizes Ivanhoe along with what Peacock calls "all the oppressions that are done under the sun" (203). Gaylord argues that Peacock accomplishes this through his characterization of Marian as a paradoxical figure, a protagonist that can be as refined as she can be hoydenish, forever negating other characters' (and readers') efforts to make sense of her as a woman in a Victorian medieval romance. Marian, Gaylord posits, is the key to understanding Peacock's "methods of obliquity" as the methods that allow the author to unsettle Victorian paradigms, especially those concerning women's roles (210).

Alexander L. Kaufman offers two well-annotated literary forgeries of the nineteenth century in "Two Ancient Ballads: 'Robin Hood's Courtship with Jack Cade's Daughter' and 'The Freiris Tragedie': An Edition." In his introduction to the poems, Kaufman explains that the works were printed in an 1822 chapbook at the behest of antiquarian James Maidment. The original chapbook, of which only twelve copies were made, presented the poems as newly rediscovered medieval works. Maidment wished to see if fellow antiquarian Robert Pitcairn could correctly

\footnotetext{
${ }^{4}$ Reviewed in the next section of this essay.

Gayle Fallon, "A Review of Robin Hood Scholarship Published in 2016." The Bulletin of the International Association for Robin Hood Studies 2 (2018): 17-34.
} 
identify the chapbook's contents as forgeries. In 1859, Maidment revealed the poems to be modern fabrications, but Pitcairn and several others had by that time mistakenly affirmed a medieval origin for the ballads. No one had challenged the authenticity of the two works. Kaufman scrutinizes the orthographical and linguistic features of both ballads, explaining how and why Pitcairn was easily duped into thinking the poems to be medieval works. He also offers thorough annotations for the ballads that at once point out the convincing medieval language of the poems while clarifying the poems' (supposed) historical and literary context.

Finally, in "The grasping, rasping Norman race': Victorian Nationalism and Sir George Alexander Macfarren's 1860 Opera, Robin Hood," Kevin J. Harty asks why Macfarren's enormously popular opera failed to remain a crowd favorite beyond the nineteenth century. Harty reasons that the English patriotism expressed in Robin Hood spoke specifically to a Victorian culture that saw itself as an "heir to a tradition that included not only Robin Hood but also King Arthur and even the Vikings" (261). Twentieth-century audiences found the opera too jingoistic, and, consequently, even most current Robin Hood scholars allow copies of the opera to gather dust.

Unlike Macfarren's Robin Hood, McSpadden and Wilson's late-Victorian publication The Adventures of Robin Hood and His Merry Outlaws (1891) has continued to enchant audiences. Paul Rüsse and Karita Nuut's piece "Rehepapp and Robin Hood: Tricksters or Heroes?"5 contrasts this popular modern collection of tales with Andrus Kivirähk's novel Rehepapp ehk november (2000), a popular modern retelling of the adventures of an Estonian folk hero. The authors parallel the legendary figures to emphasize the ways folk heroes both embrace and resist simple archetypal classification. After outlining short accounts of Rehepapp's and Robin Hood's respective cultural histories, Rüsse and Nuut read both figures as tricksters and heroes before juxtaposing them with one another. Ultimately, these readings support the authors' assertion that attempting to classify folk heroes indicates the liminal spaces they inhabit: "They do not sway only on the trickster-hero border, but also physically on the borders of where they live and where they test the abstract borders of their society" (139).

The theme of spatial liminality appears throughout the selections in Robin Hood in Outlaw/ed Spaces: Media, Performance, and Other New Directions, ${ }^{6}$ edited by Lesley Coote and Valerie B. Johnson. The volume comprises a wide-ranging study of the "timespaces" of the Robin Hood narrative. In the book's introduction, the editors explain that timespace is a "meta-cognitive concept that encourages scholars to view their individual arguments as parts of a larger whole" (4). Accordingly, the essays in this collection trace the often nebulous geographical and temporal components of the Greenwood as it is portrayed in various media. As a whole, the book invites its readers to become aware of their own part in the construction of Robin Hood stories. Readers are not simply spectating, but worldbuilding - their immersion in the Greenwood allows an active participation in the husbandry of the Greenwood as they make intertextual connections among the essays in the collection and among Robin Hood narratives from diverse media.

\footnotetext{
${ }^{5}$ Paul Rüsse and Karita Nuut, "Rehepapp and Robin Hood: Tricksters or Heroes?," Interlitteraria 21, no. 1 (2016): 130-42. http://dx.doi.org/10.12697/IL.2016.21.1.11.

${ }^{6}$ Lesley Coote and Valerie B. Johnson, eds., Robin Hood in Outlaw/ed Spaces: Media, Performance, and Other New Directions (New York: Routledge, 2016).
} 
This volume is split into two divisions: the first attends to textually transmitted spaces, such as those found in written ballads, while the second focuses on performance spaces, or "experiential space[s]," like the spaces of an archeological dig or the virtual spaces of a videogame (13). Chapter subjects appear in chronological order "to allow readers to see the tradition's progression across time" (5). This progression begins with Johnson's "A Forest of Her Own: Greenwood-space and the Forgotten Female Characters of the Robin Hood Tradition," which reveals how the Greenwood "[establishes] gender-based standards and penalties for entry into the greenwood and outlaw brotherhood" in Robin Hood and the Potter; Robin Hood's Birth, Breeding, Valour, and Marriage; and Robin Hood and Maid Marian (21). Christine Chism's "Mortal Friends in Robin and Gandelyn and the Medieval Robin Hood Ballads" then examines the ways in which death is gendered, staged, and used as a vehicle for homosocial bonding and reproduction in the titular works. In "The Play's the Thing: Establishing Boundaries in Anthony Munday's The Downfall of Robert, Earle of Huntingdon," Carrie Griffin explains how Munday self-consciously confronts the task of containing and collapsing oral and written traditions, along with changing local customs in England, in an attempt to stabilize the Robin Hood legend. Alexander L. Kaufman provides a more thorough historical context for the production of the 1822 ballad forgeries that appear in Telling Tales and Crafting Books. His "Strange Genealogies: Robin Hood's Courtship with Jack Cade's Daughter and the Creation of a Fradulent Text" suggests that literary forgeries do have a place in scholarly discussions of Robin Hood works, as they resonate with the "trickster mentality" of the tradition (83). Kristin Noone's piece "Highwaymen, Robbers, and Rogues in the Twentieth Century: A New Outlaw Fantasy" concludes the first section of the collection. Noone analyzes the 1997 anthology Highwaymen: Robbers and Rogues, in which several science fiction and fantasy authors play with temporal dislocation by positioning bandit figures of the past, such as Robin Hood, whom author Michael A. Stackpole refigures as an internet hacker known only as "Kid Binary," in unexpected timespaces. Noone stresses how these modern re-imaginings maintain the outlaw myth as a narrative central to cultural evolution in digital (and analog) futures.

The second section of Robin Hood in Outlaw/ed Spaces starts with Spencer Gavin Smith's "Property not Prophecy: Welsh 'Outlaws' Owain Lawgoch and Owain Glyn Dŵr as High Status Landowners." Smith presents a re-examination of the lives of Owain Lawgoch and Owain Glyn Dŵr informed by modern archeological discoveries. Smith argues that these discoveries reveal how Welsh rulers and noblemen compulsively worked to fulfill medieval prophecy concerning leaders, even when they had to risk land holdings, legal status, and corporal safety to do so. The next chapter, "Revisiting and Revising Robin Hood in Sixteenth-Century London," by John Marshall, shows how modern critical familiarity with several sixteenth-century sources has led to "insouciant regard for the original documents in which [several] occasions are recorded" (111). Marshall demonstrates the importance of continuing to question even well-known primary documents by revealing the disparity between modern understandings of several medieval texts as they are commonly read in current Robin Hood studies and their historical contexts. He looks specifically at sixteenth-century records of a 1502 felon called "Greneleef" who was likened to Robin Hood in several London chronicles; he also assesses documentation of the royal May festival of 1515 that featured Robin Hood, as well as Henry Machyn's written report of a Robin Hood figure in a 1559 May game. Kristi J. Castleberry provides a historical account of the 
privateer/pirate John Ward in "Sailing the Little John: John Ward and Legitimizing Outlaw Space." Though he showed an enduring love for England and English masculinity, Ward's piracy and conversion to Islam inspired English ire. Castleberry asserts that Ward was consistently demonized in contemporary culture because his legal and religious transgressions made him a difficult man to classify and contain, in contrast to traditional Robin Hood figures who, though criminals, were subservient to English royalty and the Christian Church. In "Relishing the Kill, Becoming a Man: Robin Hood's Rivalry with Guy of Gisborne," Dana Symons explores how two disparate sources, the seventeenth-century ballad Robin Hood and Guy of Gisborne and the 1922 film Douglas Fairbanks in Robin Hood, interpret Robin Hood's relationship to the brutish Guy. The former, Symons writes, "subverts the theme of fellowship common to many Robin Hood ballads" (147), even while it "evokes homosocial bonding through ritual combat" (150). The latter, however, becomes a coming-of-age story for a sexually immature Robin who must compete with the sensuous Guy for Marian's love. This bildungsroman approach “enables the assertion of American ideals of boyish masculinity" (157) and, when contrasted with the seventeenth-century ballad, confirms the labile nature of the Robin Hood legend. The following chapter focuses on the same 1922 film production. Gillian B. Anderson's "Douglas Fairbanks in Robin Hood and Its Music" documents the tumultuous creation of the musical score for the film and details how and why the entirely original orchestral compositions Fairbanks envisioned were never fully realized. Anderson states that Fairbanks "set a new standard for the motion picture industry in every area except the musical accompaniment” (170-1). The chapter "And Now Begins Our Game: Revitalizing the Ludic Robin Hood" by Thomas Rowland underscores the intromersive nature of videogames and their relationship to the Robin Hood play/game tradition. Intromersive digital spaces are, for Rowland, "virtual space[s] carved from the real, into which the audience enters in order to experience the narrative" (176). Rowland reviews the impressively long history of Robin Hoodthemed videogames in parallel with the evolution of various gaming platforms, paying special attention to Robin of Sherwood: Touchstones of Rhiannon (Adventure International, 1985), Legend of Robin Hood: Conquests of the Long Bow (Sierra On-Line,1992), and Robin Hood: Legend of Sherwood (Spellbound Studios, 2002). In all, the author situates over two dozen Robin Hood games within the history of videogame development. Stephen Knight concludes the collection with his essay "Parody and Archery: Re-Generating the Robin Hood Tradition." Knight highlights the parodic nature of the medieval Robin Hood ballads and identifies a similar nature in later Robin Hood works to show how the outlaw's legend is continuously rebirthed in popular culture through parody. The resulting individual works are thus distinct yet referential pieces in the long-standing Robin Hood tradition - parodies of parodies - that ensure both invention and replication in future Robin Hood works, as well.

In "Robin Hood: De Leyenda a Mito Cultural,"7 Richard Clouet chronicles the history and development of the texts and cultural narratives that, according to Clouet, chart Robin Hood's mythical evolution. The article is divided into two main sections following the introduction. In the first, Clouet summarizes the literary history of Robin Hood, beginning with Langland's Piers Plowman and ending with Ohlgren and Matheson's Robin Hood: the Early Poems, 1465-1560:

\footnotetext{
${ }^{7}$ Richard Clouet, "Robin Hood: De Leyenda a Mito Cultural," Revista de Filología 34 (2016): 219-33. 
Texts, Contexts, and Ideology (2007). During his summary, Clouet outlines various hypotheses offered as to the identity of a historical Robin Hood and cautiously implies that recent documentaries, such as David Baldwin's Robin Hood: The English Outlaw Unmasked, should be included in Robin Hood studies as sources that help to shape common perceptions of the outlaw's evolving character. In the second section, the author introduces Hobsbawm's definition of the social bandit in order to propose Robin's social function as the common link between the outlaw legend and the outlaw myth. Clouet then identifies character transformations that escort the legendary figure into the realm of the fantastical: Robin changes from a "cruel, egotistical and scheming" highwayman into a sylvan green man in the late 1900s (229). ${ }^{8}$ The author briefly references the works of green-man scholars such as William Anderson, Kathleen Basford, Brandon Centerwall, Timothy Husband, and María Beatriz Hernández Pérez, whose works Clouet feels support a reading of Robin Hood as a wild man or green man. Like Danièle Alexandre-Bidon, ${ }^{9}$ Clouet hints that Robin Hood may no longer connote political rebellion as much as he recalls an eco-centered spirit. Robin is now "closer to the myth [than to legend, situated in] the kingdom of faerie, in an alternative, utopian world where comradery reigns and oppression is wholly absent" (230). ${ }^{10}$

\section{FifTEENTH-CENTURY TEXTS}

Though Robin Hood tales are commonly read as popular responses to political and/or religious power, Sarah Harlan-Haughey contends that fictional representations of English outlaws can also signify "the fears and the desires of a people in a state of constant negotiation with the land they [inhabit]" (1). Harlan-Haughey's entire monograph The Ecology of the English Outlaw in Medieval Literature: From Fen to Greenwood ${ }^{11}$ is likely of interest to Robin Hood scholars, as it positions Robin Hood as a figure within the longer outlaw-tale tradition of the Middle Ages. The last two chapters of her work, "The Menace in the Greenwood: Gamelyn, Gisborne, and Little John" and "Chasing the Green Hart," contain close readings of Robin Hood texts.

The penultimate chapter explores the ways late medieval outlaw texts speak to the realistic threat of bandits who lived in or near local populations. Each of the author's points reveals the tensions a late medieval audience must have felt while listening to an outlaw tale. The fierce outlaw may punish insufferable nobles, but he also embodies a violence that is poorly restricted by woodlands bordering on peasant habitations (144). Harlan-Haughey's close readings of The Tale of Gamelyn and early Robin Hood ballads highlight parallels between animalistic outlaw feasting and ruthless battle, as well as connections between gianthood and a disregard for the fragility of human bodies. In these readings, brutal Greenwood ecology breeds the brutal outlaw. Just as

\footnotetext{
${ }^{8}$ Unless otherwise marked, all translations in this essay are mine. Clouet's text reads, "En las primeras baladas, sin embargo, Robin Hood es cruel, egoísta, y tramposo, y mantiene un control total sobre sus seguidores" (229).

${ }^{9}$ Reviewed in the last section of this essay

10 “Representa la búsqueda de una forma de vida más poética, mucho más cercana al mito y al reino de las hadas, en un mundo alternativo y utópico donde la camaradería impera y los abusos están ausentes" (230).

${ }^{11}$ Sarah Harlan-Haughey, The Ecology of the English Outlaw in Medieval Literature: From Fen to Greenwood, Outlaws in Literature, History, and Culture 1 (New York: Routledge, 2016).
} 
historical outlaws were caught in a liminal space beyond and yet still within human communities, commoners found themselves in the enigmatic space between those nobles who treated peasant bodies like cattle and those outlaws whose behaviors were predatory. While engaging in tales from the Bestial Outlaw tradition, audiences were prompted to ask what, exactly, was necessary for survival in spaces where the human can be both consumable and consumed.

Because Harlan-Haughey agrees that the Greenwood is a polysemous space filled with polysemous figures, she maintains that the Greenwood can be simultaneously brutal and whimsical. The chapter "Chasing the Green Hart" illustrates the Greenwood's many invitations to escape to a liminal wonderland where "morality, fixed identity, even humanity are unimportant $[\ldots]$ the dreamer can explore an imagined natural world free of such constraints, and infinitely playful" (179). Harlan-Haughey looks at fantastical feasting conventions, the daydream-like quality of the ever-present woodland summer, and the ubiquitous call of the wild audible in the words, "Robin Hood in Greenwood Stood," through which Robin seems to "[summon] one to enter the Greenwood and become part of his inclusive wild ecology" (186). Also included is an exploration of the hunting-of-the-hart motif as a chaotic and opportunistic endeavor that defies the traditional, organized medieval hunt. Instead, it situates the hart as a "psychopomp [that] leads the audience into the fantasy, showing them the way, and perhaps, betraying them" (189). For Harlan-Haughey, the Greenwood, like its outlaws, is an infinitely shifting wonder.

Spatial signification also features in Christine Chism's chapter "The Romance of the Road in Athelston and Two Late Medieval Robin Hood Ballads," 12 in the collection Roadworks: Medieval Britain, Medieval Roads. Chism convincingly argues that Athelston, A Lytell Geste of Robyn Hode, and Robin Hood and the Monk illustrate "the significance of roads as national connective tissue" (220). Roads in Athelston become a means of constellating separate localities with the purpose of building a national conscience-specifically, one that recognizes the same political and religious authorities. Conversely, roads in the Robin Hood ballads are used to disrupt such attempts and to propose "more fluid modes of nation as improvisation" (220). These modes involve a paradoxical use of the networks in England: Robin uses them to waylay political and religious corruption and establish his own sovereignty over the Greenwood, even while the same paths lead to Robin's affirmation of monarchical power in the Geste. The cumulative effect is a recognition that authority is a weapon, but it is, to some extent, a cooperatively created one. Therefore, the positions of those who wield authority can be cooperatively usurped. Chism compares the effects of (literal) networking in Athelston and the Robin Hood ballads to the effects of road laws decreed by the early kings Dunwallo and Belinus, recounted in Geoffrey of Monmouth's Historia regnum Britanniae. This comparison suggests that later romances echo centuries-old concerns in Britain about the methods by which a national identity is built and who should be entrusted with directing its formation.

Melissa Ridley Elmes echoes Chism's argument that Robin is an oxymoronic character who both rebels against and affirms authority. In "Conduct and Character: The Feast Scene and

\footnotetext{
${ }^{12}$ Christine Chism, "The Romance of the Road in Athelston and Two Late Medieval Robin Hood Ballads," in Roadworks: Medieval Britain, Medieval Roads, ed. Ruth Evans (Manchester: Manchester University Press, 2016), 220-48.
}

Gayle Fallon, "A Review of Robin Hood Scholarship Published in 2016." The Bulletin of the International Association for Robin Hood Studies 2 (2018): 17-34. 
Characterization in A Lytell Geste of Robyn Hode,"13 Elmes challenges the common assumption that Robin Hood should be read as an anti-hero whose main purpose is to act as a foil to the chivalric characters found in medieval romances. Instead, she recommends a polysemous reading of the outlaw, since, she argues, the feast scene alone in A Lytell Geste of Robyn Hode communicates Robin's multivalent significance. Reading Robin as polysemous "proposes criticism against established order by eschewing any effort to classify his character and, by association, his social position" (19). By close reading Robin's interactions with others in the Geste, Elmes proves that Robin is characterized not as a specific archetype, but as a complex persona whose characteristics stem from associations with "figures ranging from the holiest and most virtuous to the corrupt and most profane" (22). Robin's paradoxical social alignments testify to the many facets of his characterization. He is not simply an anti-hero, but "a freeborn man, a forester, an outlaw, a nobleman, a king, and a tricky swindler," as well as "a lord and patron, a bondsman, and a merchant" $(23,27)$. Elmes makes it clear that any attempt to flatten the outlaw's character into an archetype is as misguided as denying the complexities of language and communal experience. Simplifying the multivalent Robin Hood denies the complexity of the social anxieties Robin's character personifies, particularly those medieval anxieties surrounding religious and legal codes that repeatedly failed to curb corruption in the Church and State. In other words, Robin Hood's character is as multifaceted as the collective character of his audience and their own responses to authoritarian oppression.

Stephen Knight analyzes several medieval English-language genres as evidence of specifically English responses to oppression. In "Untraditional Medieval Literature: Romance, Fabliau, Robin Hood and 'King and Subject' Ballad,"14 Knight insists that late medieval narratives which feature lower gentry and tradesmen are not, in fact, "merely separate variants of the dominant modes of literature," such as high chivalric romance, but a collection of texts that should be read together, as they evoke late medieval anxieties related to changing power structures (601). The author notices these anxieties especially in late medieval English texts, which, he laments, have been too often dismissed as lackluster retellings of Continental stories. However, Knight identifies in English romances a distinct shift from courtly and religious affairs towards "a wider social view of the context and ethics of the hero and his interlocutors" (61). This shift signals an intentional focus on the "self-realizing" popular audience, who seem increasingly suspicious of the traditional authorities lauded in Continental romances (61). A similar inclination towards popular concerns appears when Chaucer adapts Boccaccio's fabliaux for an English-speaking audience. The fabliaux in Boccaccio's Decameron expose perceptions of social behavior but rarely dwell on the theme of intense social conflict, while Chaucer's adaptations challenge behaviormainly, the authoritarian enforcement of traditional mores. Knight details analogous challenges in

\footnotetext{
${ }^{13}$ Melissa Ridley Elmes, "Conduct and Character: The Feast Scene and Characterization in A Lytell Geste of Robyn Hode," Medieval Perspectives 31 (2016): 19-30.

${ }^{14}$ Stephen Knight, 'Untraditional Medieval Literature: Romance, Fabliau, Robin Hood, and 'King and Subject' Ballad,” in Medieval English Literature, ed. Beatrice Fannon (New York: Palgrave, 2016), 60-75.
} 
the Robin Hood tradition, such as "the determined aggression towards the civil authorities" in medieval and early modern Robin Hood texts (67). ${ }^{15}$

Knight also considers the Robin Hood of the play/games to be a testament to rebellion. He calls attention to the apparent lack of aristocratic and religious oversight during the organization and execution of events like Robin Hood ales: the play/games were instituted and managed, by and large, by the populace. Of special interest is the last section of the essay, which focuses on the "King and Subject" ballad genre, a genre that "in the late medieval period [recurs] as a way of reflecting on the interface of royal power with a new type of social entity, the self-sufficient person who does not depend on a lord for standing and income" (72). Knight explains why A Lytell Geste of Robyn Hode is a part of the "King and Subject" tradition, noting how the poem overlaps with "King and Subject" sources like Gamelyn. Overall, this essay presents a persuasive argument against the academy's tendency to venerate source texts while overlooking the cultural significance of popular retellings.

The Routledge Research Companion to Early Drama and Performance contains John Marshall's "Robin Hood Plays and Combat Games," 16 a fascinating chapter that directly addresses Stephen Knight's call for more thorough research of medieval play/games and their frequent, localized depictions of Robin Hood. ${ }^{17}$ Marshall challenges those who study Robin Hood play/games to consider local intent and regional context before coming to any conclusion about the socio-cultural functions of play/games. This is not least because different forms of combat (those with predetermined outcomes and those without, for instance) may work to create phenomenologically different events for both spectators and contestants. Marshall models how to carefully consider the regional disparities and economic positions of play/game participants throughout his essay. His commentary on the Paston play Robyn Hod and the Shryff off Notyngham is especially instructive. While comparing documents related to the Paston play and records of the play/games of Litcham, Marshall observes that the dramatis personae of the Paston play are servants of the Paston household, forced to enact scripted combat that resonates with irony: they must act out a fictional response to aristocratic abuse while in the service of abusive - and very real - aristocrats (175-176). The actors of Litcham, however, are awarded prizes for winning unscripted contests included in otherwise scripted performances. Disparities such as these must be acknowledged if scholars are to understand how Robin Hood play/games worked to express widely varying local interests.

\section{EARLY MODERN WORKS}

\footnotetext{
${ }^{15}$ Here, Knight analyzes Robin Hood and the Monk, Robin Hood and the Potter, Robin Hood and Guy of Gisborne, and $A$ Lytell Geste of Robyn Hode.

16 John Marshall, "Robin Hood Plays and Combat Games," in The Routledge Research Companion to Early Drama and Performance, ed. Pamela M. King (New York: Routledge, 2016), 170-84.

${ }^{17}$ Stephan Knight, "Which Way to the Forest? Directions in Robin Hood Studies," in Robin Hood in Popular Culture: Violence, Transgression, and Justice, ed. Thomas Hahn (Cambridge: D. S. Brewer, 2000), 111-28.
} 
In the article "Heroic Performance: The Multiple Temporalities of Shakespeare's Robin Hoods,"18 Andrew James Johnston examines three Shakespearean texts that complicate "the temporal cliché frequently linked to the concept of the hero as warrior" (60). This cliché manufactures nostalgia for a past era by positioning the warrior as a metonym for traditional values. Nonetheless, the plays As You Like It, The Two Noble Kinsmen, and Pericles, Prince of Tyre invoke Robin Hood as a means of "reflecting on, critiquing and possibly even deconstructing their own complicity in the politics of temporality and periodization" (62). Robin Hood is named explicitly in As You Like It as a way to invoke the clichéd notion that heroes no longer exist; however, in The Two Noble Kinsmen, Robin Hood's name becomes synonymous with the ballad genre and its material form, the broadsheet. Because broadsheets were "the socially lowest type of literature Elizabethan/Jacobean England's literary field had to offer" (64), The Two Noble Kinsmen directly opposes the notion of Robin as an epic hero. Johnston mentions that, by the time The Two Noble Kinsmen was being performed on stage, local authorities had effectively squashed the low-brow play/games featuring Robin, which suggests a conflicted perception of the outlaw in England, ashe recalls both a chivalric hero and an ignoble street fighter. The Elizabethan stage consequently labors to juggle the two connotations. Johnston's explication of the Prologue to Pericles is the most controversial of his readings: Johnston claims that John Gower's speech contains an opaque reference to Whitsuntide ales, and, by extension, Robin Hood play/games. Shakespeare's Gower conjures hints of "the carnivalesque that contemporary Protestant aesthetic sensibilities would easily have associated with the Old Religion" (68). Consequently, Shakespeare's Robin Hoods are situated both atemporally, as artifacts of nostalgia, and temporally, as dated reminders of an allegedly less progressive past. In frustrating any singular temporal situation, Shakespeare makes Robin "the hero who refuses to succumb to Renaissance strategies of ordering time and understanding history" (72).

In his article "Robin Hood's Rules: Gang-culture in Early-modern Outlaw Tales?" 19 Neil Cartlidge asserts that the legend of Robin Hood continues to be popular after the Middle Ages not because his character is infinitely endearing, but because audiences sense an implicit, conflicted connection between themselves and those groups that surround the outlaw. Cartlidge credits Eric Hobsbawm ${ }^{20}$ with revealing a complex sociology linked to bandits whose lives and livelihoods depend upon popular sympathy. He then complicates Hobsbawm's work by exploring how Robin Hood, even when divorced from the sympathies of his medieval audience, "can still have a relevance [and] function as an imaginative paradigm" (15). Cartlidge coins the term imaginative persistence to describe the continuing presence of centuries-old legends. Such persistence permits, for example, Sir Gawain and Sherlock Holmes to retain idiosyncratic traits in anachronistic contexts. These traits must, Cartlidge says, be few and somewhat elastic if a legendary figure is to translate well in texts long removed from the figure's originating culture. For Robin Hood, "what

\footnotetext{
18 Andrew James Johnston, "Heroic Performance: The Multiple Temporalities of Shakespeare's Robin Hoods," Shakespeare Jahrbuch 152 (2016): 60-72.

${ }^{19}$ Neil Cartlidge, "Robin Hood's Rules: Gang-culture in Early-modern Outlaw Tales?," Cultural Dynamics 28, no. 1 (2016): 13-26.

${ }^{20}$ Eric Hobsbawm, Bandits (London: Weidenfeld and Nicolson, 1969).

Gayle Fallon, “A Review of Robin Hood Scholarship Published in 2016." The Bulletin of the International Association for Robin Hood Studies 2 (2018): 17-34.
} 
meaning he possesses is necessarily heuristic" and "it is only his subversiveness that survives across texts, and across time" (16).

This subversiveness can, especially in sixteenth- and seventeenth-century texts, be easily transferred to a kind of gang-culture that affects the way Robin and his associates police those in political power. Cartlidge explicates ballads in the Forresters Manuscript to demonstrate this transference: members of the public are absorbed into Robin's band, the Merry Men appear as a "lynch mob" (20), and Robin relies almost entirely on the presence of his threatening "gang" to affect a type of "rough justice" (20). The Forresters Manuscript ballads imply a "lower-class" (23) audience, one reluctant to identify with forms of criminality but willing to approve of rough justice as long as they are not individually indicted in the process. ${ }^{21}$ Cartlidge argues that Robin's subversiveness is therefore less responsible for his perpetual popularity than the perpetual presence of a lower-class, oppressed audience that is conflicted over its desire to personally punish authorities. In Cartlidge's own words, "the Robin Hood tradition owes a great deal to the fact that Robin is a man with a gang [which enables audiences] to become complicit in the deeds that [Robin] does and, at the same time, to impose on him a kind of complicity in the values that they themselves hold" (23), especially those values that demand justice when punishers must, according to their own laws, be punished.

Robin Hood's ability to mete out punishment and its relationship to gender performativity is addressed in Simone Chess' "Doublecrossdressing Encounters: Haec Vir and Hic Mulier, The Faerie Queene, May Day, and 'Robin Hood and the Bishop."'22 This is the first chapter in the author's monograph Male-to-Female Crossdressing in Early Modern English Literature: Gender, Performance, and Queer Relations, ${ }^{23}$ in which Chess promotes a rigorous examination of men dressing as women on the early modern stage and in early modern literature. MTF crossdressing during the English Renaissance, she notes, has received little scholarly attention when compared to cases of FTM crossdressing, though MTF crossdressing consistently creates instances of relational, beneficial male femininity that contributes to the greater good in the literary works Chess explores throughout her book. In her first chapter, Chess establishes the theoretical foundation for the rest of her monograph and models how she combines close reading and queer theory. Chess views moments of doublecrossdressing, in which FTM crossdressing occurs alongside MTF crossdressing, as performances that confirm a lack of causality in gender performance at large. These performances discover the prosthetic nature of the wardrobe as that which mobilizes gendered bodies acting in relation to one another. Early modern doublecrossdressing plots are therefore "a demonstration of a kind of out-of-body genderqueer

\footnotetext{
${ }^{21}$ I wish to clarify that when Cartlidge uses the adjective "lower-class" to describe the intended audience of early modern ballads (23), he is not implying that the manuscript itself necessarily has lower-class origins, only that the contents appealed to those who were not aristocrats. Because "lower-class" is a notoriously slippery term in Medieval Studies, however, it is wise to recognize that the owner of the physical Forresters Manuscript was likely aristocratic or, at the very least, relatively wealthy and well-educated. (See Eckhardt and Smith's Manuscript Miscellanies in Early Modern England, pp. 58-9).

${ }^{22}$ Simone Chess, "Doublecrossdressing Encounters: Haec Vir and Hic Mulier, The Faerie Queene, May Day, and 'Robin Hood and the Bishop,"' in Male-to-Female Crossdressing in Early Modern English Literature: Gender, Performance, and Queer Relations (New York: Routledge, 2016), 39-71.

${ }^{23}$ For a more thorough review of this work, see John Garrison's review in Early Modern Culture 12 (2017): 97-8. 
fluidity in which one queer act of crossdressing enables and even encourages another," even though, Chess warns, it is necessary to acknowledge that crossdressing is only made possible by "the larger machine of normative sex, sexuality, and gender performance" (42).

The chapter's subsection about Robin Hood and the Bishop is relatively short. In three pages, Chess discusses the ballad and evaluates the scene in which Robin and the Old Woman exchange clothing so they can effectively punish the Bishop. Chess includes some short comments about the early modern woodcuts that accompany the work, observing that the first woodcut's depiction of the clothing swap highlights the prosthetic function of clothes by blurring physiological features: "The image captures the moment of doublecrossdressing, but we don't know which side of the transformation we are seeing" (59). Despite the "fixed, binary bod[ies]" that dominate the end of the ballad, the profitable exchange of outerwear confirms that, for early modern audiences, "gender swapping can be a potentially revolutionary and subversive tool" (60, $61)$.

\section{EighteEnTH-CENTURY TeXtS}

In his article "Robin Hood the Brute: Representations of the Outlaw in Eighteenth Century Criminal Biography," ${ }^{24}$ Stephen Basdeo argues that negative depictions of Robin Hood in eighteenth-century narratives evince a public aversion to the notion of a righteous criminal. The author references Lincoln B. Faller's categorizations for eighteenth-century thieves who appear in criminal biographies: these thieves were portrayed as heroes, brutes, or buffoons. Following Faller, Basdeo maintains that the Robin Hood of the 1700s most often plays the role of the brute. The article is split into several sections. The first contains an explanation of the century's print culture context, and the second, third, and fourth sections record typical chronological presentations of Robin Hood's criminal biography. Eighteenth-century news sources stoked fears of a progressive crime wave, and these fears were fortified by thousands of newly published criminal biographies aimed primarily at middle-class consumers. Though Robin Hood was usually treated as a historical outlaw in such biographies, his backstory and parentage began to vary widely from source to source. This, Basdeo notes, is interesting to Robin Hood scholars, since the ongoing gentrification of the literary Robin Hood was interrupted at a time when the populace was most wary of criminal activity, even though the concept of a "criminal class" was not yet fully formed. The idea that a historical Robin Hood stole from the rich to give to the poor was replaced with the cynical association of the outlaw with all highwaymen. Robin is debased when he is depicted as a leader of "banditti," a "common footpad" instead of a skilled equestrian, and a traitor to the Crown (656). Collectively, these depictions support Basdeo's overarching argument that Robin Hood was, indeed, most frequently positioned as a brute instead of a hero (or a buffoon) in criminal biographies of the 1700s. Basdeo concludes that these biographical accounts influenced the

\footnotetext{
${ }^{24}$ Stephen Basdeo, "Robin Hood the Brute: Representations of the Outlaw in Eighteenth Century Criminal Biography," Law, Crime and History 6, no. 2 (2016): 54-70.

http://www.lawcrimehistory.org/journal/vol.6\%20issue2\%202016/Badeo\%20Robin\%20hood\%20formatted\%20final .pdf.
}

Gayle Fallon, "A Review of Robin Hood Scholarship Published in 2016." The Bulletin of the International Association for Robin Hood Studies 2 (2018): 17-34. 
evolution of the Robin Hood legend in later years, and may have been persuasive enough to affect Scott's characterization of Robin Hood in Ivanhoe.

\section{NineteENTH-CENTURY NOVELS}

Lorraine Kochanske Stock's "Medievalism and Proto-Feminism in Two Late Nineteenth-Century Novels_-Maid Marian and Robin Hood: A Romance of Old Sherwood Forest (1894) and The Romantic History of Robin Hood (1898)" 25 exposes proto-feminist themes in two late Victorian Robin Hood novels. Stock begins the essay with a useful history of Maid Marian, charting both Marian's character development and the fickle interest audiences seemed to have in her until the nineteenth century, when she was regularly featured in drama and fiction. (Stock remarks that Howard Pyle's exclusion of Marian in his 1883 The Merry Adventures of Robin Hood is a notable exception here. Pyle's Marian is reduced to a singular, fleeting thought in the mind of her love interest, and she is curiously absent from the rest of the work.) When J. E. Preston Muddock and Barry Pain published Maid Marian and Robin Hood: A Romance of Old Sherwood Forest and The Romantic History of Robin Hood, respectively, they "transformed Robin Hood's now-expected love interest by giving Marian an intrinsic function in the male hero's exploits, thus rendering Marian an important component of the Robin Hood master-narrative" (145). The rest of the article is dedicated to explicating Marian's impact on this master-narrative through her personal development, both as a multi-dimensional character and as a self-possessed love interest for Robin. A compelling feature of Stock's readings of Muddock and Pain is her consideration of other female characters in the novels. Stock points to Tennyson's character Kate in the drama The Foresters: Robin Hood and Maid Marian as a possible inspiration for additional female characters in later works. The powerful, active roles of these women reinforce Stock's conclusion that nineteenthcentury medievalism "anticipated the influence of feminism by seven decades" (158).

\section{Twentieth- ANd Twenty-First-Century Media ANd NarRatives}

Meriem Pages' "Saracens Abroad: Imagining Medieval Muslim Warriors on the Silver Screen"26 examines five films-The Crusades (1935); The Black Knight (1954); Robin Hood: Prince of Thieves (1991); Robin Hood: Men in Tights (1993); and Kingdom of Heaven (2005) —and how they significantly "part from the medieval tradition of representing the Muslim Other" (5). Pages ultimately claims modern evocations of the medieval Saracen to be a "[reinforcement of] the prevailing image of the Middle Ages as dark and primitive" (17). This is, in part, because Muslims in these films appear as exceptional individuals whose morals and actions contrast with those of

\footnotetext{
${ }^{25}$ Lorraine Kochanske Stock, "Medievalism and Proto-Feminism in Two Late Nineteenth-Century Novels—Maid Marian and Robin Hood: A Romance of Old Sherwood Forest (1894) and The Romantic History of Robin Hood (1898)," Medieval Perspectives 31 (2016): 137-60.

${ }^{26}$ Meriem Pages, "Saracens Abroad: Imagining Medieval Muslim Warriors on the Silver Screen," Essays in Medieval Studies 32 (2016): 5-21.
}

Gayle Fallon, "A Review of Robin Hood Scholarship Published in 2016." The Bulletin of the International Association for Robin Hood Studies 2 (2018): 17-34. 
large (and largely fictionalized) Muslim communities. In addition, individuals are usually metonyms for a Western ideal that stands in direct opposition to a contemporary threat depicted as "a faceless and highly dangerous Muslim horde" (6). For example, in The Crusades, the clever, subtle Saladin serves as a contrast to his barbaric followers, who participate in a book-burning riot strangely reminiscent of the Nazi book bonfires of 1933. Similarly, the character Azeem in Robin Hood: Prince of Thieves is portrayed positively, but the character cannot return to his Muslim homeland on pain of death. Pages notes that this cultural rejection speaks to Azeem's role as the "good" Muslim, or as "the exception that proves the rule" (14). Pages cites the work of Ross Brann to highlight the concomitant racial commentary in the odd link between Costner's Robin Hood and white American males, and between Freeman's Azeem and "[Robin's] African American counterpart" (14). Such commentary not only reinforces the stereotypes it purports to eradicate; it obscures the problematic but "very real interest in Islam and hope for Muslim conversion to Christianity" that medieval authors and audiences seem to have had (17). Accordingly, Pages observes, modern films predictably refigure medieval Muslims in thoroughly modern terms, and in doing so, they rewrite the modern as medieval, dangerously misrepresenting both.

In "De Heroínas y Mujeres: La Trayectoria Cinematográfica del Personaje de Lady Marian," 27 Gema Pérez Herrera and Julia Pavón Benito similarly examine the Other in Robin Hood films by surveying Maid Marian's changing roles on screen. The authors identify Marian's purpose in several productions ${ }^{28}$ and identify key feminist advances that allowed directors to develop Marian's role as Robin Hood's "catalyst" ${ }^{29}$ into that of an agentic hero (Últimas Décadas). Of special note is the authors' insistence on the agency of even early depictions of Marian. In Allan Dwan's Robin Hood (1922), Marian acts as a catalyst for Robin's maturation, but this "does not make her an overly passive person or a mere decoration, as some have said" — instead, she is "key to the hero's formation" (Antecedentes del Cine Clásico). ${ }^{30}$ This assessment does not assume that Marian's catalytic function is a feminist one, just as Marian's progressive "masculinization" 31 in the $70 \mathrm{~s}, 90 \mathrm{~s}$, and $2000 \mathrm{~s}$ does not, for the authors, prove to be unquestionably beneficial (Últimas Décadas). More recent films have failed to present romantic individuals who possess similar strengths in equal measure, as, for example, Ridley Scott's Robin Hood seems to suffer from a specific weakness of character in order to highlight Marian's prowess (Marian Apunta al Futuro). In their conclusion, the authors ask the reader to ponder whether or not Robin and Marian's romance can survive a Hollywood egalitarianism that may not permit the gender performances responsible for motivating the silver screen Robin Hoods of the past.

\footnotetext{
${ }^{27}$ Gema Pérez Herrera and Julia Pavón Benito, "De Heroínas y Mujeres: La Trayectoria Cinematográfica del Personaje de Lady Marian,” Arbor 192, no. 779 (2016). http://dx.doi.org/10.3989/arbor.2016.779n3010.

${ }^{28}$ The films most discussed in this essay are as follows: Dwan's Robin Hood (1922); Curtiz's The Adventures of Robin Hood (1938); Annakin and Disney's The Story of Robin Hood and His Merrie Men (1952); Disney's Robin Hood (1973); Lester's Robin and Marian (1976); Reynolds's Robin Hood: Prince of Thieves (1991); Irvin's Robin Hood (1991); Hewitt's The Princess of Thieves (2001); Scott's Robin Hood (2010).

29 “catalizadora” (Últimas Décadas).

30 "Esto no hace de ella un personaje meramente pasivo o decorativo, como a veces se señala, sino que es clave para la configuración del héroe" (Antecedentes del Cine Clásico).

31 "masculinización" (Últimas Décadas).
}

Gayle Fallon, "A Review of Robin Hood Scholarship Published in 2016." The Bulletin of the International Association for Robin Hood Studies 2 (2018): 17-34. 
Questions of a different sort of sustainability arise in Danièle Alexandre-Bidon's "Robin Hood, ou comment la BD contribue à la construction d'un mythe moderne." 32 This chapter is included in Le Moyan Âge en bande dessinée, a collection of essays edited by historian Tristan Martine. The volume explores the relationship between the historical Middle Ages and their lasting influence on the imaginations of modern comic artists and readers. Alexandre-Bidon's chapter is of interest to Robin Hood scholars, as it summarizes the functions of numerous Robin Hood figures in comic strips since the early twentieth century. Alexandre-Bidon proves that comic-strip versions of Robin have undeniably informed modern Robin Hood mythology, particularly in France, where some modern illustrators have actively resisted the gentrification the outlaw has experienced in Anglophone countries. Éditions Vaillant, for instance, intentionally names Robin "the common people's knight errant" 33 so as to emphasize his rebel status and limit associations with aristocracy (261). Some French illustrators also transform the Norman invaders who feature in many modern Robin Hood narratives into Norse invaders, a change that removes possibly defamatory connotations with Normandy. Changes such as this have, Alexandre-Bidon says, made Robin Hood more of a mutable "prince of values" 34 than a legendary prince of thieves (265). Consequently, his cause can be readily translated into modern concerns: "His avatars now battle...waste and pollution with the intent to promote sustainable development: an honorable role, but not an overtly heroic one... an image of our own society, perhaps?" (265). ${ }^{35}$

This last selection is included because it is one of few sources to document current, personal affect related to outlaw mythology. In her monograph Crime, Prisons and Viscous Culture: Adventures in Criminalized Identities, Finola Farrant identifies what she calls the "viscous" connections among personal prison narratives, systemic powers, and cultural connotations regarding punishment and justice. Farrant emphasizes the intertextuality and intersectionality apparent in the prison narratives she details throughout her book. Doing so supports her argument that culture is inherently "viscous" because its components are intrinsically fluid and "sticky," adhering to and sometimes absorbing anything they touch (7). These qualities result in a sort of cultural cross-contamination that hinders attempts to identify cultural features of any one place and time - and this is why, Farrant argues, any narrative, whether fiction or non-fiction, must be read as an ever-evolving product of an intertextual, intersectional network of stories.

In her chapter "Lone Ranger, Robin Hood, the Wild One and Ghetto Supastar," 36 Farrant points out "viscous connections between outlaw mythology and lived experiences" (79). Farrant's interview with a man called "Phil" is especially intriguing. Phil left a mundane career in an oil company when he began to see the company as a harbinger of "the dystopian future, which was set out before him in the form of never ending corridors and rows of cyborgian automatons" (88). Phil began cashing large checks that his friends had purposely misplaced, and he soon quit his job.

\footnotetext{
${ }^{32}$ Danièle Alexandre-Bidon, "Robin Hood, ou comment la BD contribue à la construction d'un mythe moderne," in Le Moyan Âge en Bande Dessinée, ed. Tristan Martine (Paris: Karthala, 2016), 255-70.

33 “"le chevalier errant du peuple"” (qtd. in Alexandre-Bidon, 261)

34 "prince des valeurs" (265)

35 "Ses avatars combattent...le gaspillage, la pollution, avec pour objectif de promouvoir le développement durable: un rôle honorable, mais sans plus rien d'épique... à l'image de notre société?" (265).

${ }^{36}$ Finola Farrant, "Lone Ranger, Robin Hood, the Wild One and Ghetto Supastar," in Crime, Prisons, and Viscous Culture: Adventures in Criminalized Identities (London: Palgrave Macmillan, 2016), 79-100.
} 
At the time, he rationalized his actions by imagining himself as Robin Hood, fighting against large banks and corporations by stealing from them and redistributing the wealth among his friends. Farrant cites other prisoners' narratives to stress the intertextual nature of criminal identity formation. Even though some individuals are unaware of the intertextual connections that shape their identities, Farrant discovers a Robin Hood legend that permeates Western prison walls, linking those outside with those within, and, at times, urging those on either side to rationalize their actions in terms of outlaw justice.

\section{CONCLUSION}

This review testifies to the astonishingly wide array of sub-genres within current Robin Hood scholarship. Most writers reviewed above mention, at least once, the tenacity of the Robin Hood figure: he survives to live in all centuries, in all contexts. Many Robin Hood scholars have confirmed that part of the appeal of Robin Hood is his polysemous and ever-shifting nature. It is clear that this polysemy has fostered not only an enduring legend, but a rich scholarly tradition. 


\section{BIBLIOGRAPHY}

Alexandre-Bidon, Danièle. "Robin Hood, ou comment la BD contribue à la construction d'un mythe moderne." In Le Moyan Âge en Bande Dessinée, edited by Tristan Martine, 255-70. Paris: Karthala, 2016.

Basdeo, Stephen. "Robin Hood the Brute: Representations of the Outlaw in Eighteenth Century Criminal Biography." Law, Crime and History 6, no. 2 (2016): 54-70. http://www.lawcrimehistory.org/journal/vol.6\%20issue2\%202016/Badeo\%20Robin\%20h ood\%20formatted\%20final.pdf.

Cartlidge, Neil. "Robin Hood's Rules: Gang-culture in Early-modern Outlaw Tales?" Cultural Dynamics 28, no. 1 (2016): 13-26.

Chess, Simone. "Doublecrossdressing Encounters: Haec Vir and Hic Mulier, The Faerie Queene, May Day, and 'Robin Hood and the Bishop."' In Male-to-Female Crossdressing in Early Modern English Literature: Gender, Performance, and Queer Relations, 39-71. New York: Routledge, 2016.

Chism, Christine. "The Romance of the Road in Athelston and Two Late Medieval Robin Hood Ballads." In Roadworks: Medieval Britain, Medieval Roads, edited by Ruth Evans, 22048. Manchester: Manchester University Press, 2016.

Clouet, Richard. "Robin Hood: De Leyenda a Mito Cultural.” Revista de Filología 34 (2016): 219-33.

Coote, Lesley, and Valerie B. Johnson, eds. Robin Hood in Outlaw/ed Spaces: Media, Performance, and Other New Directions. Outlaws in Literature, History, and Culture 2. New York: Routledge, 2016.

Delony, Mikee. "A Review of the Year's Publications in Robin Hood Scholarship." The Bulletin of the International Association for Robin Hood Studies 1 (2017): 32-43.

Eckhardt, Joshua, and Daniel Starza Smith, ed. Manuscript Miscellanies in Early Modern England. New York: Routledge, 2016.

Elmes, Melissa Ridley. "Conduct and Character: The Feast Scene and Characterization in $A$ Lytell Geste of Robyn Hode." Medieval Perspectives 31 (2016): 19-30.

Farrant, Finola. Crime, Prisons and Viscous Culture: Adventures in Criminalized Identities. London: Palgrave Macmillan, 2016.

Garrison, John. Review of Male-to-Female Crossdressing in Early Modern English Literature: Gender, Performance, and Queer Relations, by Simone Chess. Early Modern Culture 12 (2017): 97-8.

Harlan-Haughey, Sarah. The Ecology of the English Outlaw in Medieval Literature: From Fen to Greenwood. Outlaws in Literature, History, and Culture 1. New York: Routledge, 2016.

Hobsbawm, Eric. Bandits. London: Weidenfeld and Nicolson, 1969.

"Hood, Robin (England)." In Folk Heroes and Heroines around the World, 2nd ed., edited by Graham Seal and Kim Kennedy White, 251-254. Denver, CO: Greenwood, 2016.

Johnson, Valerie B. Review of Telling Tales and Crafting Books: Essays in Honor of Thomas H. Ohlgren, edited by Alexander L. Kaufman, Shaun F. D. Hughes, and Dorsey Armstrong. Arthuriana 27, no. 1 (2017): 139-42. 
Johnston, Andrew James. "Heroic Performance: The Multiple Temporalities of Shakespeare's Robin Hoods." Shakespeare Jahrbuch 152 (2016): 60-72.

Kaufman, Alexander L., Shaun F. D. Hughes, and Dorsey Armstrong, eds. Telling Tales and Crafting Books: Essays in Honor of Thomas H. Ohlgren. Festschriften, Occasional Papers, and Lectures XXIV. Kalamazoo: Medieval Institute Publications, 2016.

Knight, Stephen. "Untraditional Medieval Literature: Romance, Fabliau, Robin Hood and 'King and Subject' Ballad.” In Medieval English Literature, edited by Beatrice Fannon, 60-75. New York: Palgrave, 2016.

—. "Which Way to the Forest? Directions in Robin Hood Studies." In Robin Hood in Popular Culture: Violence, Transgression, and Justice, edited by Thomas Hahn, 111-28. Cambridge: D. S. Brewer, 2000.

Marshall, John. "Robin Hood Plays and Combat Games." In The Routledge Research Companion to Early Drama and Performance, edited by Pamela M. King, 170-84. New York: Routledge, 2016.

Pages, Meriem. "Saracens Abroad: Imagining Medieval Muslim Warriors on the Silver Screen." Essays in Medieval Studies 32 (2016): 5-21.

Pérez Herrera, Gema, and Julia Pavón Benito. "De Heroínas y Mujeres: La Trayectoria Cinematográfica del Personaje de Lady Marian.” Arbor 192, no. 779 (2016). http://dx.doi.org/10.3989/arbor.2016.779n3010.

Rüsse, Paul, and Karita Nuut. "Rehepapp and Robin Hood: Tricksters or Heroes?" Interlitteraria 21, no. 1 (2016): 130-42. http://dx.doi.org/10.12697/IL.2016.21.1.11.

Stock, Lorraine Kochanske. "Medievalism and Proto-Feminism in Two Late Nineteenth-Century Novels-Maid Marian and Robin Hood: A Romance of Old Sherwood Forest (1894) and The Romantic History of Robin Hood (1898)." Medieval Perspectives 31 (2016): 137-60.

Gayle Fallon, "A Review of Robin Hood Scholarship Published in 2016." The Bulletin of the International Association for Robin Hood Studies 2 (2018): 17-34. 